\title{
Corm Weight-Dependent Reproduction of Pinellia ternata
}

\author{
Tohru Tominaga* and Akiko Nakagaki*
}

\begin{abstract}
Pinellia ternata (Thunb.) Breit. is an Araceae perennial weed and reproduces by seeds, bulbils produced on both lamina joints and petioles, and cormlets. The relationship between its reproductive mode and corm weight was investigated.
\end{abstract}

In April, 1992, two hundred fifty corms were sampled in a flower garden, weighed, planted individually in $11 \mathrm{~cm}$ diameter $\times 10 \mathrm{~cm}$ depth pots filled with soil from a vegetable field and dug up in October, 1992. The number of leaves expanded, bulbils and scapes formed were recorded over time. Weight of each bulbil was measured individually.

Four different leaf types were produced in order as the plant grew, representing separate growth stages. These were the cordate, auriculate, tripartite and ternately compound leaf stages. Individuals in the cordate leaf stage seldom produced reproductive organs. Only a few individuals in the auriculate leaf stage produced bulbils on petioles, while almost all of the individuals in the tripartite leaf stage did so. All individuals in the ternately compound leaf stage produced bulbils on both lamina joints and petioles. Flowering plants always had ternately compound leaves and corm fresh weight heavier than $0.79 \mathrm{~g}$. Number of leaves expanded, bulbils produced, and bulbil weight were highly related to corm weight. Reproduction of this weed was inferred to be closely dependent on corm weight.

\footnotetext{
* Faculty of Agriculture, Shinshu University Ina, Nagano 399-45, Japan

(Accepted November 6, 1996)
}

Key words: Pinellia ternata, corm weight dependent reproduction, perennial weed, reproductive mode

\section{Introduction}

Pinellia ternata (Thunb.) Breit. is an Araceae perennial weed widely distributed in orchards and vegetable fields of Japan. This species has a very complicated reproductive system. It reproduces both sexually and asexually. Asexual reproduction is made by forming cormlets, bulbils on lamina joints and petioles (Fig. 1). The recruitment of offspring is mainly by bulbil formation.

Four different leaf types are produced in order as the plant grows, representing separate growth stages. These are the cordate, auriculate, tripartite and ternately compound leaf stages ${ }^{6}$. From observation of natural populations, it was suggested that leaf shape and size seem to be largely dependent on corm size and therefore bulbil formation may also be controlled by corm size, because bulbils are formed on leaves.

It is very important to elucidate weed reproductive systems to establish rational weed control systems, but there have been only a few studies on this species ${ }^{2,3)}$.

In this study, expansion of leaves and the formation of scapes and bulbils were observed over time in individuals with different initial corm sizes to determine the relationship between reproductive mode and corm size. Reproductive mode dependent on corm size and the reason for this weed's persistence in fields despite frequent weeding were discussed. 


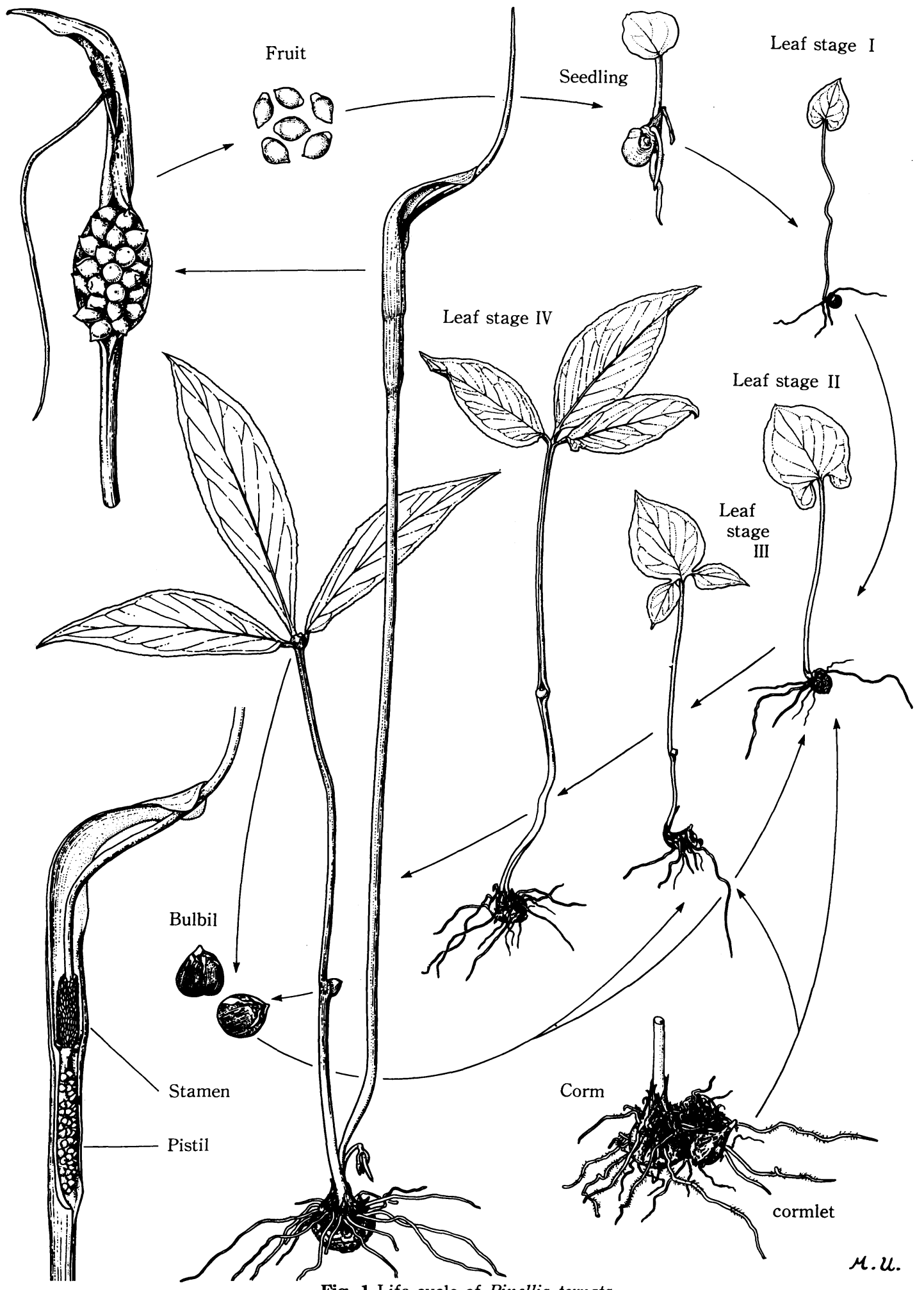

Fig. 1 Life cycle of Pinellia ternata. 


\section{Materials and Methods}

On April 12, 1992, 250 corms were sampled from a natural population of $P$. ternata in a flower garden and the fresh weight of each corm was measured. Corms were planted individually at a depth of $9 \mathrm{~cm}$ in $11 \mathrm{~cm}$ diameter $\times 10 \mathrm{~cm}$ deep unglazed pots filled with soil from a vegetable field. Pots were kept under natural conditions.

After planting, leaf emergence, leaf stage and formation of scapes and bulbils were observed daily and the number of ovaries per flower was counted. Four leaf stages, cordate, auriculate, tripartite and ternately compound leaf stage, were classified according to Tominaga ${ }^{6}$. Bulbils formed on lamina joints were collected after they matured and their fresh and dry weights were measured individually.

On October 28, 1992, when aerial parts had died, corms and bulbils formed on petioles were dug up and the number of bulbils was counted. Fresh and dry weight of each corm and bulbil were measured. Dry weight measurement was made after at least 48 hours at $80^{\circ} \mathrm{C}$.

Linear and nonlinear regression were used to decribe the relationship between initial corm fresh weight and the number of leaves expanded, number of bulbils formed, mean bulbil weight and total bulbil weight. For nonlinear regression, the model, $\mathrm{Y}=\mathrm{a} \log \mathrm{X}+$ b was used, where $Y$ is number of leaves expanded, number of bulbils formed or mean bulbil weight; $\mathrm{X}$ is initial corm fresh weight. Nonlinear parameters were fitted to the data for least squares estimation of nonlinear parameters.

\section{Results and Discussion}

No plants emerged from twelve corms having fresh weight of less than $0.18 \mathrm{~g}$, but plants from the residual 238 corms emerged and expanded one to 14 leaves per plant in succession over the growing season, April to October. Light corms seemed unable to emerge from the depth of $9 \mathrm{~cm}$, as described of the emergence of seeds of Trifolium subterraneum L. ${ }^{1}$, Lithospermum caroliniense (Walt.) $\mathrm{MacM}^{7}$ and Desmodium puniculatum L. $\mathrm{DC}^{8}$. As plants grew, transition from lower leaf stages to higher ones was generally found in the cordate and auriculate leaf stages (Fig. 2). This transition may result from an increase in corm weight due to allocation of photosynthate, because it was found in a natural population that greater corm weight was correlated with higher leaf stage and larger leaf area ${ }^{6}$. In contrast, 69. $7 \%$ of individuals in the tripartite leaf stage remained in that stage, and the residual 30 . $3 \%$ changed to the ternately compound leaf stage. Also, $52.2 \%$ of individuals in the ternately compound leaf stage stayed in the same stage and $41.2 \%$ changed to the tripartite leaf stage, $5.9 \%$ to the auriculate, and 0 . $7 \%$ to the cordate leaf stage. In individuals of

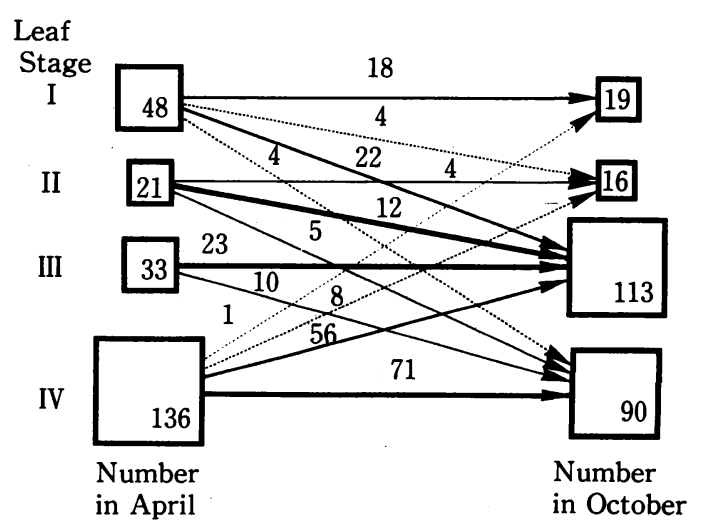

Fig. 2 Leaf stage transition during the growing season from April to October.The number of individuals passing through each stage is shown. Leaf stage I, II, III and IV indicate cordate, auriculate, tripartite and ternately compound leaf stage, respectively. 
higher leaf stages, most photosynthate appears to be allocated to bulbils produced on leaves and flowers.

As shown in Fig. 3, the number of leaves expanded per plant over the growing season increased logarithmically as corm initial fresh weight increased. Heavier corms stock more reserves and can expand more leaves than smaller ones. Moreover, $P$. ternata's reproductive mode varied with its leaf stage (Fig. 1). Individuals in the cordate leaf stage seldom produced reproductive organs. In the auriculate leaf stage, bulbils on petioles were only infrequently produced. In contrast, individuals in the tripartite leaf stage formed

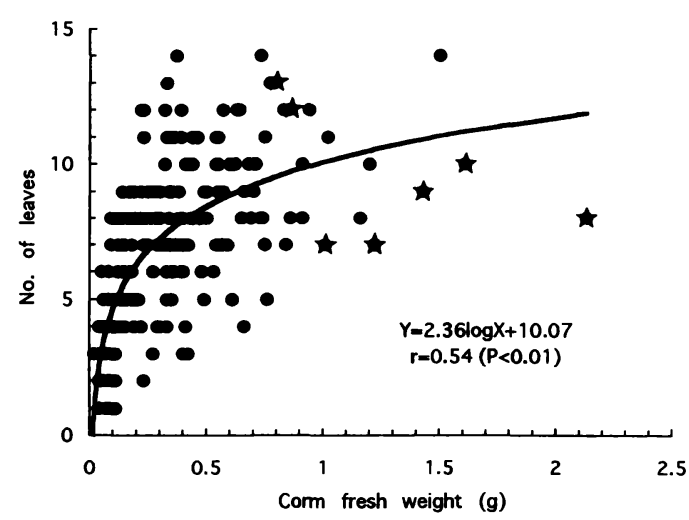

Fig. 3 Effect of initial corm weight on the number of leaves expanded.

$\star$ Individual which formed scape(s).

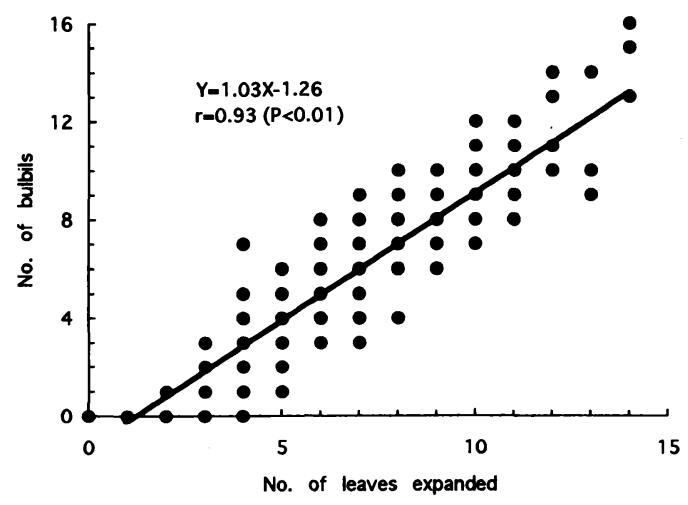

Fig. 4 Effect of leaf expansion on bulbil production. bulbils on petioles with only a few exceptions. Almost all individuals in the ternately compound leaf stage produced bulbils both on lamina joints and petioles. During the experiment only seven plants produced scapes. One out of these seven formed three scapes and two had two scapes. Bulbils are heavier than seeds, although fewer in number, and are more advantageous in emergence and primary growth.

This weed has probably been selected to allocate more photosynthate to corms and bulbils instead of seeds under agricultural practices. Flowering individuals always had ternately compound leaves and their corm fresh weight at planting was always greater than $0.79 \mathrm{~g}$. In Arisaema urashima Hara, an Araceae perennial residing on the forest floor, a relationship was found between individual biomass and the number of seeds produced per plant ${ }^{5)}$, but such relationship was not found between number of ovaries per flower and corm fresh weight in P. ternata. Bulbils are formed on leaf lamina joints and petioles, and therefore, as shown in Fig. 4, the number of leaves expanded per plant directly controlled the number of bulbils produced per plant. As a result, the number of bulbils produced per plant also increased as corm fresh weight increased (Fig. 5). Mean number of bulbils produced per plant was $5.5 \pm 3$. 6 and the maximum number of bulbils produced was 16 . As corm fresh weight increased, mean bulbil weight (Fig. 6) and total bulbil weight produced per plant (Fig. 7) significantly increased. Plants with heavier corms can expand more and larger leaves and as a result accumulate more photosynthate than plants with lighter corms. As a bulbil is a reserve stock organ, individuals with larger corms have larger leaf and consequently can produce more and heavier bulbils. 


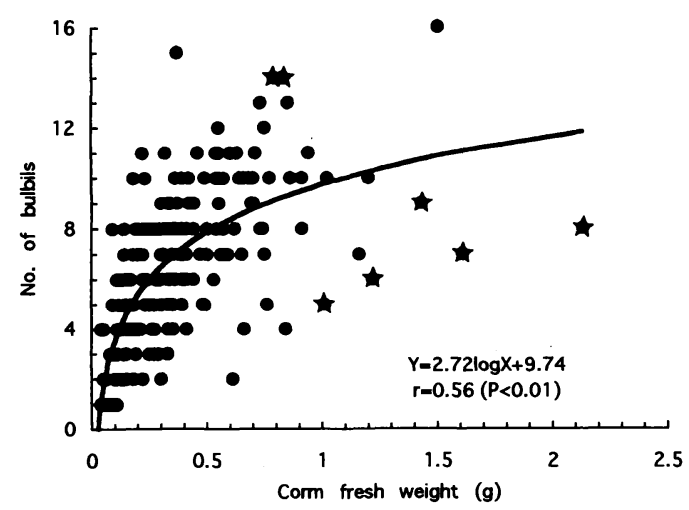

Fig. 5 Relationship between corm weight and number of bulbils produced.

$\star$ Individual which formed scape(s).

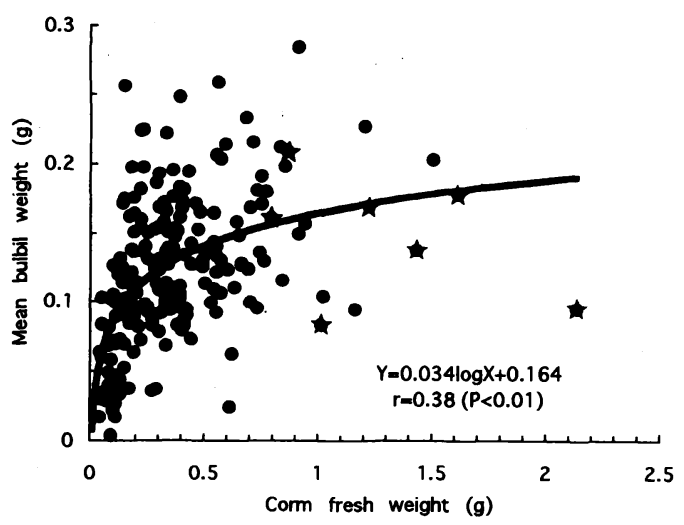

Fig. 6 Relationship between corm weight and mean bulbil weight.

$\star$ Individual which formed scape(s).

A trade-off between seed size and number is generally found ${ }^{4}$, but in this weed a high positive correlation was found between the number of bulbils produced and mean bulbil weight (Fig. 8). As mentioned above, plants with heavier corms expanded more and larger leaves, and therefore such plants probably have enough productive capacity to overcome the conflict between the number and size of bulbils.

Figure 9 shows the increase in corm fresh weight over the growing season from April to October. Most plants increased in corm fresh

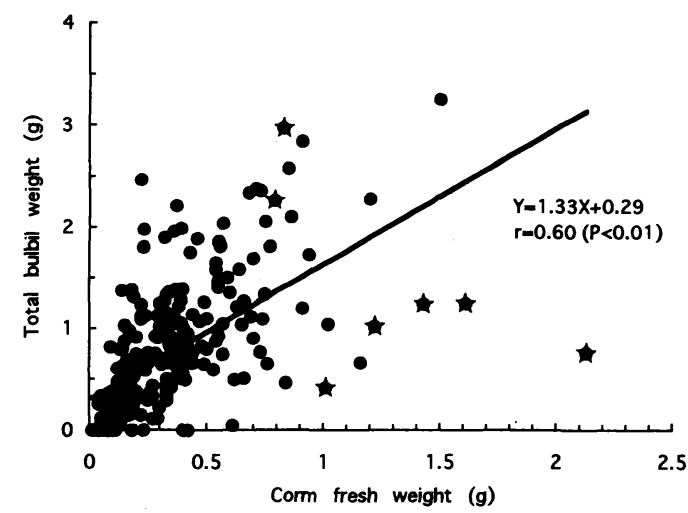

Fig. 7 Relationship between corm weight and total bulbil weight.

$\star$ Individual which formed scape(s).

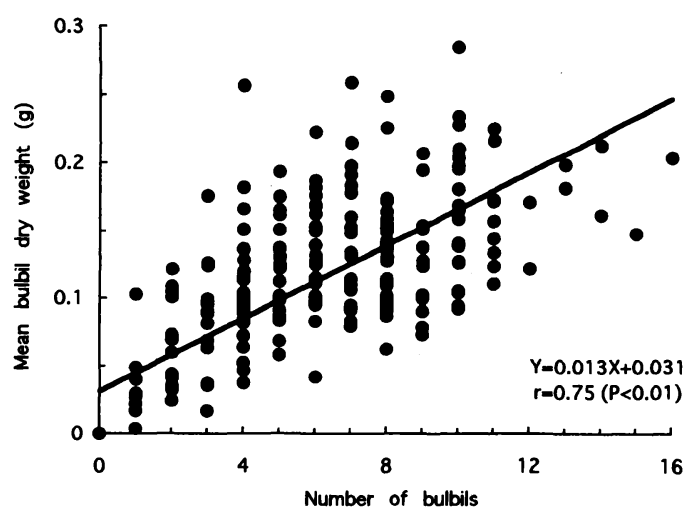

Fig. 8 Relationship between number of bulbils formed and mean bulbil weight.

weight up to a maximum of 25 -fold, but 31 plants decreased in corm fresh weight; the latter included the 12 corms from which no plants emerged. Eight plants expanded only one small cordate leaf. Their corms were very small at planting in spring. They may have exhausted their corm reserves to expand leaves and therefore could not stock much reserve in corms.

This weed produced more and heavier bulbils in response to the increase in corm weight. Bulbils were formed on tripartite and ternately compound leaves and leaf stage was 


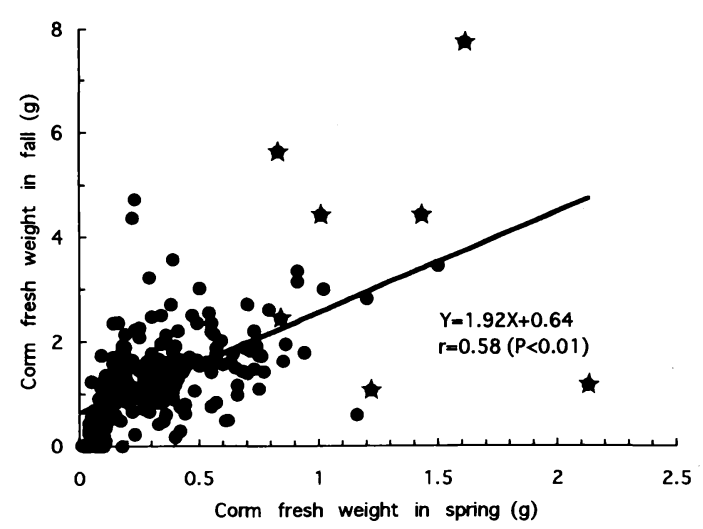

Fig. 9 Change in corm weight from spring to fall. $\star$ Individual which formed scape(s).

largely dependent on corm weight. Since individuals in the tripartite and ternately compound leaf stages accounted for about $60 \%$ of a natural population ${ }^{6}$, they would play an important role in the recruitment of offspring of this weed.

This vigorous vegetative reproductive capacity may be one of the reasons for the persistence of this weed population despite weeding in the field, and corm weight is a very important factor controlling the reproductive system of this weed.

\section{Acknowledgement}

The authors gratefully acknowledge $\mathrm{Mr}$. M. Umebayashi for his fine illustration.

球茎重に依存したカラスビシャクの繁殖様式

冨永 達*・中垣明子*

\section{摘 要}

サトイモ科の多年生雑草カラスビシャク (Pinellia ternata (Thunb.) Breit.) は、種子、珠芽および球

* 信州大学農学部

\section{References}

1) Black, J. N. 1956. The influence of seed size and depth of sowing on pre-emergence and early vegetative growth of subterranean clover (Trifolium subterraneum L.). Australian Journal of Agricultural Research 7, 98-109.

2 ) Nagao, Y. 1980. Growth of flower stalks and seed setting of Pinellia ternata Breit. Weed Research, Japan 25, 15-19. (in Japanese with English summary).

3 ) Sasaki, T. and S. Yamazaki 1968. Growth and Reproduction of Pinellia ternata Breit. Weed Research, Japan 7, 34-37. (in Japanese with English summary).

4 ) Stebbins, G. L. 1971. Adaptive radiation of reproductive characteristics in angiosperms, II. Seeds and seedlings. Annual Review of Ecology and Systematics 2, 237-260.

5) Takasu, H. 1987. Life history studies on Arisaema (Araceae) I. Growth and reproductive biology of Arisaema urashima Hara. Plant Species Biology 2, 29-56.

6) Tominaga, T. 1992. Relationship between leaf stage and corm weight of Pinellia ternata. Weed Research, Japan 37 (Suppl.), 132-133. (in Japanese).

7) Weller, S. G. 1985. Establishment of Lithospermum caroliniense on sand dunes: the role of nutlet mass. Ecology 66, 1893-1901.

8 ) Wulff, R. D. 1986. Seed size variation in Desmodium paniculatum II. Effects on seedling growth and physiological performance. Journal of Ecology 74, 99-114.
茎によって繁殖する (Fig. 1)。本研究では, 親球茎 の重さと繁殖様式の関係を検討した。

1992年 4 月上旬に信州大学農学部構内の花塤から カラスビシャクの球茎250個を掘り取り,個々の球茎 の重量を測定した後, 野菜畑の土を詰めた直径 $11 \mathrm{~cm}$ ・ 深さ $10 \mathrm{~cm}$ の素焼き鉢に球茎を 1 個づつ植えた。生育 期間中, 展開葉数, 花茎数, 珠芽数およびその重量 を調査した。地上部が完全に枯死した10月下旬に親 球茎を掘り取り，重量を測定した。

カラスビシャクは, 4 種類の葉身, 即ち, 心形の 
葉身，基部がややくびれた葉身，基部が深くくびれ 左右の裂片葉が明らかな葉身, および完全に分離し た 3 小葉からなる葉身を展開した。心形の葉身をも つ個体はほとんど繁殖器官を形成しなかったが, 基 部がややくびれた葉身をもつ個体のほとんどは葉柄 に珠芽を形成した。基部が深くくびれ, 左右の裂片 葉が明らかな葉身をもつ個体はすべて葉柄と葉身の 基部に珠芽を形成した。花茎を抽出した個体はすべ て完全に分離した 3 小葉からなる葉身をもち, 植え 付け時の親球茎の重さが0.79g 以上の個体であった。 展開葉数 (Fig. 3), 珠芽形成数 (Fig. 5), 珠芽重 (Fig. 6,7) は球茎重が重くなるにつれ增加した。カラス ビシャクの繁殖様式は, 親球茎の重さに大きく依存 していることが推定された。

キーワード：カラスビシャク, 球茎, サイズ依存繁 殖, 多年生雑草, 繁殖様式 